\title{
Dinâmica da infecção natural pelo Anaplasma marginale em vacas e bezerros da raça Holandesa, na região de Londrina, Estado do Paraná, Brasil ${ }^{1}$
}

\author{
Dynamic of the natural infection by Anaplasma marginale in Holstein \\ cows and calves in the Londrina region, North of Paraná State, Brazil
}

\author{
Richard C. Pacheco ${ }^{2}$; Odilon Vidotto ${ }^{3 *}$; Kátia Tamekuni'; Michelle Igarashiं; Paula \\ Kawasaki ${ }^{4}$; Leonardo B. Prudêncio ${ }^{4}$ Elizabeth R. M. Marana ${ }^{4}$; Ademir Luz Pereira ${ }^{3}$
}

\section{Resumo}

\begin{abstract}
A dinâmica da infecção por Anaplasma marginale em vacas e bezerros da raça Holandesa foi estudada em duas propriedades leiteiras (A e B) com manejos distintos da região Norte do Paraná. Na propriedade A as vacas eram mantidas no sistema "tie-stall" e, os bezerros em bezerreiros coletivos; na propriedade $\mathrm{B}$, as vacas em sistema "free-stall" e os bezerros em gaiolas individuais. A cada 15 dias efetuou-se a contagem de carrapatos e coletas de amostras de sangue das vacas e seus respectivos bezerros. As vacas foram monitoradas dos 45 dias antes até 60 dias após o parto, e seus bezerros, do nascimento até 240 dias de idade. A parasitemia foi determinada em esfregaços sangüíneos corados pelo Giemsa. O sangue total e as amostras de soro obtidas foram submetidos, respectivamente, as técnicas da PCR e cELISA. Nas vacas os níveis de imunoglobulinas diminuíram próximo ao parto, além de apresentarem uma dinâmica de anticorpos diferentes entre as duas propriedades. Na propriedade A os níveis de anticorpos aumentou entre 30 e 60 dias após o parto e na $\mathrm{B}$ os anticorpos permaneceram em níveis baixos no período de monitoramento das vacas. Os níveis de anticorpos dos bezerros da propriedade A que não eram altos no dia do nascimento, diminuíram ainda mais até 45 dias pós-parto e voltou a crescer a partir de 60 dias, com pico máximo aos 105 dias. Na propriedade B, onde os bezerros apresentavam níveis mais elevados de anticorpos no primeiro dia de vida, houve uma diminuição mais demorada dos níveis, alcançando o ponto mais baixo aos 75 dias pós-parto e voltou a crescer bem mais tardiamente, aos 165 dias de idade. Pela PCR, detectou-se $A$. marginale no sangue de bezerros das duas propriedades, a partir dos 45 dias de vida, com a maioria das amostras de sangue positivas entre 105 e 180 dias. As vacas e bezerros de ambas as propriedades foram expostos ao carrapato Boophilus microplus durante grande parte do período de monitoramento e mostraram parasitemia variando de 0 a $1 \%$. A infecção natural dos bezerros pelo $A$. marginale após o nascimento foi mais dependente dos níveis de anticorpos colostrais absorvidos do que da intensidade da infestação pelo $B$. microplus. As diferenças de manejo existentes nas duas propriedades influenciaram os níveis de anticorpos das vacas e bezerros e o período de infecção natural dos bezerros.
\end{abstract}

Palavras-chave: Anaplasma marginale, cELISA, PCR, vacas holandesas, bezerros.

\footnotetext{
Apoio financeiro do CNPq, CAPES e CPG/UEL.

2 Pós-Graduando em Epidemiologia Experimental e Aplicada às Zoonoses, nível Doutorado, do Departamento de Medicina Veterinária Preventiva e Saúde Animal, Faculdade de Medicina Veterinária e Zootecnia, Universidade de São Paulo, São Paulo, Brasil.

3 Professor Dr. Universidade Estadual de Londrina (UEL), Centro de Ciências Agrárias (CCA), Departamento de Medicina Veterinária Preventiva (DMVP), Campus Universitário, Cx Postal 6001, CEP 86051-990, Londrina, Paraná, Brasil; e-mail: vidotto@uel.br.

4 Pós-Graduando em Ciência Animal, nível Mestrado, área de Sanidade Animal, UEL, CCA, DMVP.

* Autor para correspondência.
} 


\begin{abstract}
The dynamic of the infection by Anaplasma marginale in Holstein cows and calves was studied in two dairy farms (A and B) in the Londrina region, North of Paraná. In the farm A the cows were maintained in the tie-stall system and, the calves in collective stall; in the farm B, the cows stayed in freestall system and the calves in individual cages. Every 15 days, blood samples were collected from the dams 45 days before parturition until 60 days post partum, and from their calves at birth until 240 days of age. Tick burden counting was also performed on dams and calves twice a month. Percentage of infected erythrocytes was established by Giemsa-stained smears. Blood and sera samples were examined by Polimerase Chain Reaction (PCR) and competitive Enzime-Linked Immunosorbent Assay (cELISA), respectively. In the cows, the anti- $A$. marginale antibody levels decreased close to the parturition, showing an adverse behavior among the farms. In the farm A the levels of antibodies increased between 30 and 60 days after the parturition and, in farm B the antibodies stayed in low levels during the accompaniment period of the cows. The anti-A. marginale antibody levels of the calves of the farm A, that were not high in the day of the birth, decreased more until 45 days post parturition and it increased again starting from 60 days, with maximum pick to the 105 days. In the farm B, where the calves presented higher levels of antibodies at the birth day, there was a slower decrease of the antibody levels, reaching the lowest point to the 75 days post parturition and it increased again more tardily, to the 165 days of age. The dams and calves in both farms were exposure to cattle tick Boophilus microplus during almost all period of accompaniment and they showed rickettsemia ranging from 0 to $1 \%$. In conclusion, A. marginale infection after birth was more influenced by maternal antibody levels than tick burden; the differences between animals handling influenced the antibody levels of the dams and calves, and during the natural infection period of the calves; tick burden did not influence the rickettsemia in the studied farms.
\end{abstract}

Key words: Anaplasma marginale, cELISA, PCR, cows and calves.

\section{Introdução}

A anaplasmose bovina é uma infecção intraeritrocítica causada pelo Anaplasma marginale (THEILER, 1910), que pertence à ordem Rickettsiales, família Anaplasmataceae (DUMLER et al., 2001). A enfermidade tem distribuição mundial (RISTIC, 1981), representando um grande obstáculo à produção de carne e leite nas regiões tropicais e subtropicais (ERIKS et al., 1989).

A transmissão do $A$. marginale tem sido motivo de muita controvérsia em relação aos meios e mecanismos de transmissão e a importância epidemiológica dos possíveis vetores (KESSLER, 2001). A transmissão biológica por várias espécies de ixodídeos tem sido demonstrada experimentalmente (STILLER; COAN, 1995). No Brasil, o Boophilus microplus (CANESTRINI, 1887), carrapato de bovinos, tem sido incriminado como o principal transmissor de $A$. marginale (FARIAS, 1995; MARTINS; CORREAA, 1995) e também em outras regiões tropicais e subtropicais (ALONSO et al., 1992).

A transmissão transovariana não ocorre normalmente no B. microplus (CONNELL; HALL,
1972; RIBEIRO; LIMA, 1996). No entanto, apesar dessa espécie de carrapato manter-se sobre o hospedeiro durante sua fase de vida parasitária, foi comprovado que, freqüentemente, mudam de hospedeiro, ao deslocar-se do local de fixação do instar anterior para fixar-se e reiniciar a alimentação do novo instar (CONNELL; HALL, 1972; MASON; NORVAL, 1981; KESSLER, 2001).

Os animais que sobrevivem à infecção aguda permanecem persistentemente infectados por vários anos, com níveis microscópicos indetectáveis de eritrócitos infectados, menores que $0,01 \%$ de células parasitadas (ERIKS et al., 1989; KIESER; ERIKS; PALMER, 1990). Esses animais permanecem como reservatórios importantes na transmissão mecânica direta de eritrócitos infectados com $A$. marginale e como fonte de infecção aos carrapatos ixodídeos (PALMER; RURANGIRWA; BROWN, 1999).

O conhecimento da epidemiologia da infecção por A. marginale na população é de grande importância na formulação de programas de controle. A anaplasmose apresenta uma dinâmica de transmissão mais complexa que a babesiose e o aparecimento de surtos a campo, em regiões tropicais e subtropicais, 
não está totalmente esclarecida por que não existe informação segura a respeito de seus transmissores, modo de transmissão, vetores e reservatórios (VANZINI; RAMIREZ, 1994), portanto, os mecanismos de transmissão da anaplasmose em bovinos na natureza constituem um interessante campo de estudo (RIBEIRO; LIMA, 1996).

O presente trabalho teve como objetivo estudar, pelo Ensaio de imunoadsorção enzimática competitivo (cELISA), Reação em Cadeia pela Polimerase (PCR) e acompanhamento da população de $B$. microplus, a dinâmica da infecção por $A$. marginale em vacas e bezerros da raça Holandesa na região de Londrina, Norte do Paraná.

\section{Material e Métodos}

O presente trabalho foi conduzido em duas propriedades de rebanho leiteiro da região de Londrina (A e B), localizadas ao Norte do Estado do Paraná, no período de agosto de 2001 a novembro de 2002. A variação média da precipitação pluviométrica foi de $125.4 \mathrm{~mm}$, e a temperatura média mínima de $16.5^{\circ} \mathrm{C}$ e a máxima de $28.4{ }^{\circ} \mathrm{C}$ durante o período experimental (IAPAR, 2002).

Foram selecionadas dez vacas gestantes na propriedade A e 11 na propriedade B, durante os últimos dois meses de gestação. As vacas das duas propriedades eram da raça Holandesa, mantidas em confinamentos tipos "free-stall" e "tie-stall", respectivamente. Na propriedade A (produtora de leite tipo A), após o nascimento, os bezerros permaneciam com suas mães por um período de três a seis horas até ingerirem o colostro ou, se necessário, o mesmo era administrado a partir da ordenha da própria vaca ou obtido de um banco de colostro mantido na propriedade e, posteriormente eram levados do piquete de parição a um bezerreiro coletivo. Enquanto que na propriedade B (produtora de leite tipo B), era realizada a administração de colostro aos bezerros após o nascimento em mamadeira, com o produto fresco retirado da vaca logo após o parto, administrado à vontade e, em seguida, os animais permaneciam em gaiolas individuais de madeira no interior de um barracão coberto. O aleitamento artificial, nas duas propriedades, foi realizado até os 60 dias de idade e após este período os bezerros eram transferidos para pequenos piquetes, onde tinham acesso ao pasto, além da suplementação a base de ração comercial, feno e sal mineral ad libitum desde os primeiro dias de vida.

Durante o período experimental a infestação das vacas e bezerros pelo B. microplus de ambas as propriedades foi monitorada, de acordo com a técnica de contagem de ixodídeos proposta por Wharton e Utech (1970). Foram colhidas duas amostras de sangue, uma contendo EDTA e a outra sem o anticoagulante, das 21 fêmeas prenhes selecionadas (10 animais na propriedade $A$ e 11 animais na propriedade B), para realização dos exames sorológicos e parasitológicos, no período entre 45 dias antes até 60 dias após o parto em intervalos quinzenais. No dia do parto, além da obtenção das duas amostras de sangue de cada vaca, foram colhidas também duas amostras de sangue de cada bezerro, conforme descrito acima, entre 12 a 24 horas após o nascimento. Os bezerros também foram monitorados a cada 15 dias até completarem 240 dias de idade. A colheita de sangue foi realizada pela punção da veia jugular, em tubos estéreis com vácuo.

As amostras de sangue colhidas com EDTA foram utilizadas na confecção de lâminas com esfregaços delgados de sangue, para a determinação da parasitemia (INSTITUTO INTERAMERICANO DE COOPERATION PARA LA AGRICULTURA, 1984), extração do DNA a partir da técnica que emprega os reagentes: fenol-clorofórmio/álcoolisoamílico (THEIL et al., 1981) e sílica/tiocianato de guanidina (BOOM et al., 1990), modificada por Alfiere (1999) e descrita por Shimada (2002) para o A. marginale, realização da PCR e determinação do volume globular utilizando a técnica de microhematócrito. Das amostras de sangue sem o anticoagulante foi retirado o soro após a separação e retração do coágulo para a realização da técnica de cELISA descrita por Knowles et al. (1996). 
Os níveis de anticorpos colostrais transferidos aos bezerros foram submetidos à análise estatística pelo teste $\mathrm{t}$ de Student (VIEIRA, 1998).

\section{Resultados e Discussão}

A Figura 1 mostra os resultados do monitoramento sorológico nas vacas das propriedades A e B, onde se verifica uma pequena diminuição da porcentagem de inibição média de anticorpos à medida que se aproximava o dia do parto. Na propriedade A esta porcentagem foi menor na última colheita que antecedeu o parto, com sete animais soropositivos no cELISA, e na primeira colheita após o parto, com oito animais soropositivos, enquanto na propriedade $\mathrm{B}$, a menor média de inibição ocorreu na primeira colheita após o parto, quando apenas cinco animais eram soropositivos pelo cELISA.

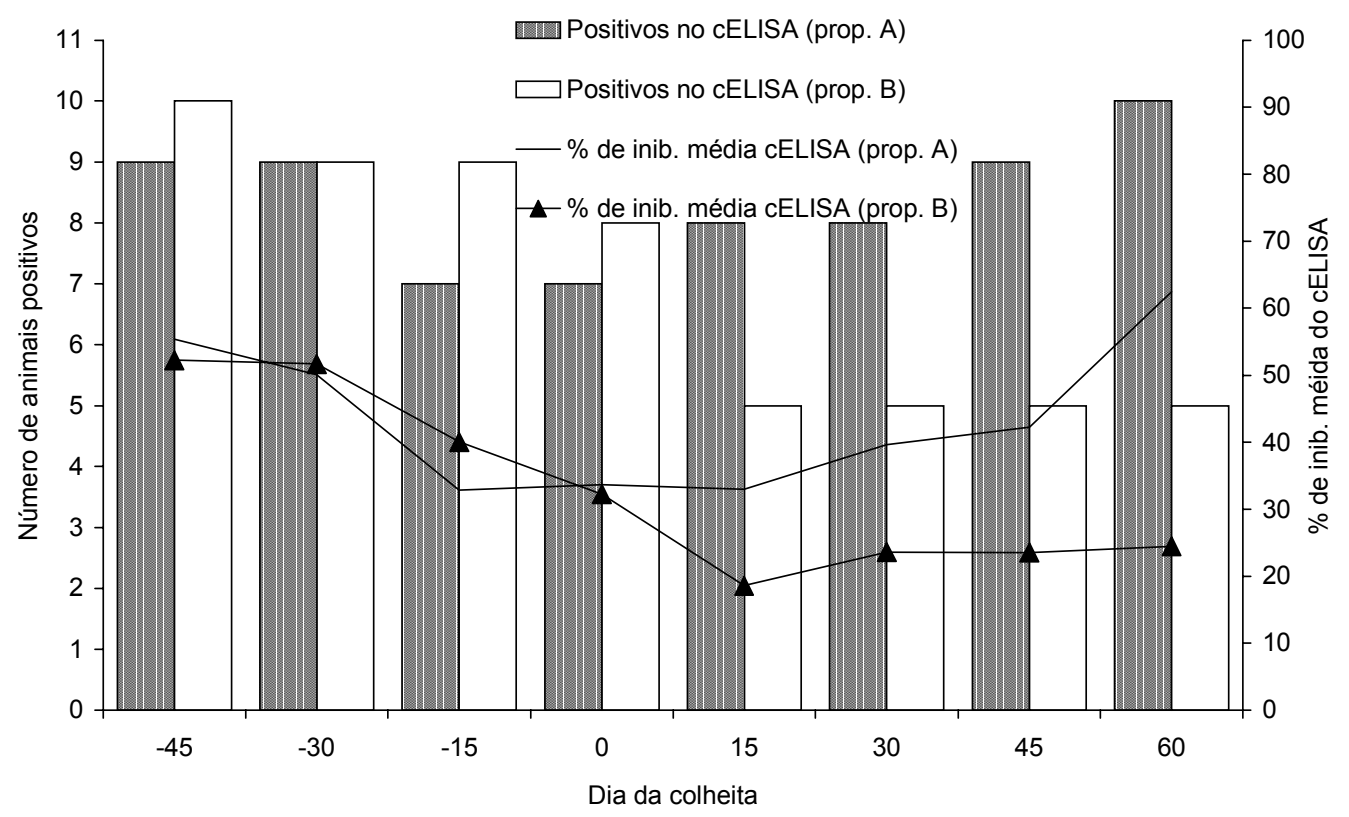

Figura 1. Distribuição dos animais positivos e freqüência de distribuição da porcentagem de inibição média para o $A$. marginale pela técnica de cELISA em soros de vacas da raça Holandesa, no período pré e pós- parto, quinzenalmente, nas propriedades A e B, na região de Londrina, PR, entre agosto de 2001 a novembro de 2002

O presente estudo mostrou que os níveis de anticorpos séricos caem no período peri-parto, como constatado nas duas propriedades acompanhadas, provavelmente em conseqüência da intensa migração de imunoglobulinas da corrente sangüínea para a glândula mamária que ocorre na formação do colostro no período que antecede o parto (SASAKI; DAVIS; LARSON, 1976). No entanto, a evolução dos níveis de anticorpos após este período mostrou um comportamento adverso entre as duas propriedades, provavelmente em função do tipo de manejo dos animais em relação ao B. microplus. Assim, na propriedade $\mathrm{A}$, onde as vacas foram mais expostas ao carrapato durante o experimento, houve uma recuperação dos níveis de anticorpos séricos superiores aqueles existentes por volta dos 45 dias antes do parto. Por outro lado, as vacas da propriedade $\mathrm{B}$, com reduzida exposição ao carrapato, mantiveram-se com baixos níveis de anticorpos séricos (Fig.1). A intensidade da infestação pelo $B$. microplus não influenciou os níveis médios de parasitemia que oscilaram entre 0,1 e 1,1\%, considerados subparasitêmicos e persistentes em animais portadores sãos de $A$. marginale (ERIKS et al., 1989; PALMER; BROWN; RURANGIRWA, 2000). Isso explicaria alguns surtos de anaplasmose que tem ocorrido na região em vacas no período periparto as quais foram mantidas por uma ou duas 
lactações livres de carrapatos e depois colocadas em piquetes infestados com larvas de B. microplus nos meses que antecederam o parto (dados não publicados).

A Figura 2 mostra a evolução dos níveis de anticorpos séricos dos bezerros do nascimento aos 240 dias de idade na propriedade A. Na média, os bezerros apresentaram baixa porcentagem de inibição ao nascimento, o que pode indicar um manejo do colostro inadequado, levando a uma falha na transferência da imunidade passiva e, conseqüentemente baixos teores de imunoglobulinas séricas nos animais. Quarenta e cinco dias após o nascimento todos os bezerros eram negativos quanto à presença de anticorpos contra $A$. marginale, conseqüentemente, neste período esses animais estavam desprotegidos contra a infecção natural a campo. A partir dos 60 dias de idade os níveis de anticorpos séricos aumentaram, o que resultou em um número maior de animais positivos e aos 105 dias todos os bezerros eram soropositivos para anticorpos contra A. marginale, permanecendo até o final do monitoramento. Portanto, uma queda acentuada no nível de anticorpos colostrais contra A. marginale foi observada a partir do nascimento e atingiu os valores mais baixos (\% de inibição média) aos 45 dias de vida dos bezerros. Observa-se, a partir dos 105 dias de idade dos bezerros, valores mais elevados de inibição pelo cELISA, que se mantiveram constantes até o final do período de observação.

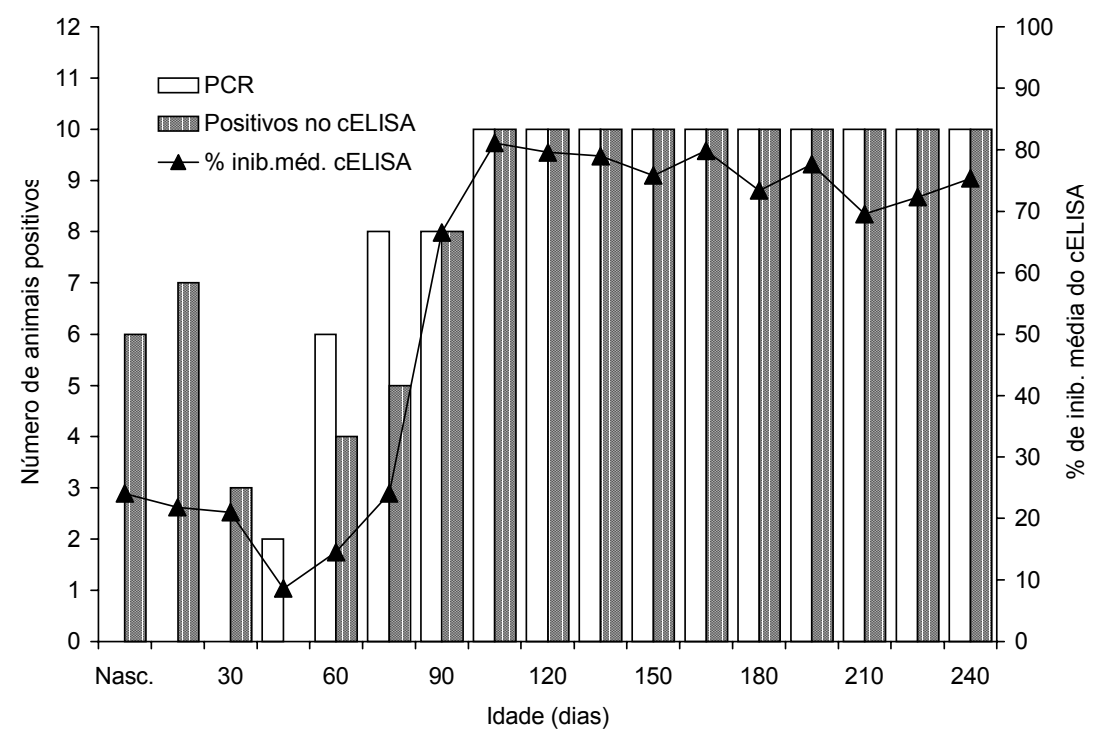

Figura 2. Distribuição dos animais positivos pela técnica de cELISA e da PCR, e a freqüência de distribuição da porcentagem de inibição média para o A. marginale pelo cELISA, realizada em dez bezerros, segundo a faixa etária, na propriedade A, na região de Londrina, PR. entre agosto de 2001 a novembro de 2002.

O aumento na porcentagem de inibição média, que ocorreu a partir dos 60 dias de idade dos bezerros, indica a produção ativa de anticorpos específicos contra $\mathrm{o} A$. marginale, certamente devido à infecção adquirida após o nascimento. Todas as amostras de sangue dos bezerros submetidas a PCR foram negativas ao nascimento. A infecção foi detectada pela primeira vez aos 45 dias de idade, em dois bezerros, e o número de animais positivos na PCR aumentou para oito trinta dias após, até a detecção da infecção em todos os bezerros aos 105 dias de idade, onde se pode observar os valores mais elevados nos níveis de anticorpos séricos pela porcentagem de inibição média do cELISA (Fig.2).

A Figura 3 mostra que os anticorpos maternos transferidos aos bezerros na propriedade $\mathrm{B}$, tiveram em média níveis mais elevados que na propriedade A, mostrando, portanto uma melhor transferência de 
anticorpos colostrais contra $A$. marginale. Essa diferença entre as propriedades foi estatisticamente significativa $(t=2,4281 ; p=0.0252)$. Esses valores diminuíram de forma mais lenta após o nascimento, alcançando o valor mais baixo aos 120 dias de idade. Esta queda mais prolongada dos níveis de anticorpos séricos protegeu os animais por um período de tempo mais longo (60 dias) e em parte retardou a infecção natural pelo carrapato, como pode ser constatado pela evolução no número de animais positivos na PCR, em relação aos animais da propriedade A. Aos 135 dias de idade, apenas dois bezerros eram sorologicamente positivos para a presença de anticorpos contra A. marginale. Somente a partir dos 165 dias de idade que os níveis de anticorpos séricos aumentaram significativamente, resultando em um número maior de animais positivos com porcentagem de inibição média mais elevada aos 195 dias de idade, que se manteve até o final do experimento. Da mesma forma que na propriedade A, todas as amostras de sangue dos bezerros, da propriedade B, submetidas a PCR foram negativas no dia do nascimento. A infecção foi detectada pela primeira vez, também aos 45 dias de idade, em 4 bezerros, e o número aumentou progressivamente, até a detecção da infecção máxima em 10 (dez do total de 11 bezerros) aos 195 dias de idade. Curiosamente, um bezerro (número 10) manteve-se negativo, tanto no cELISA, quanto na PCR até os 240 dias de idade, quando o experimento foi encerrado (Fig.3).

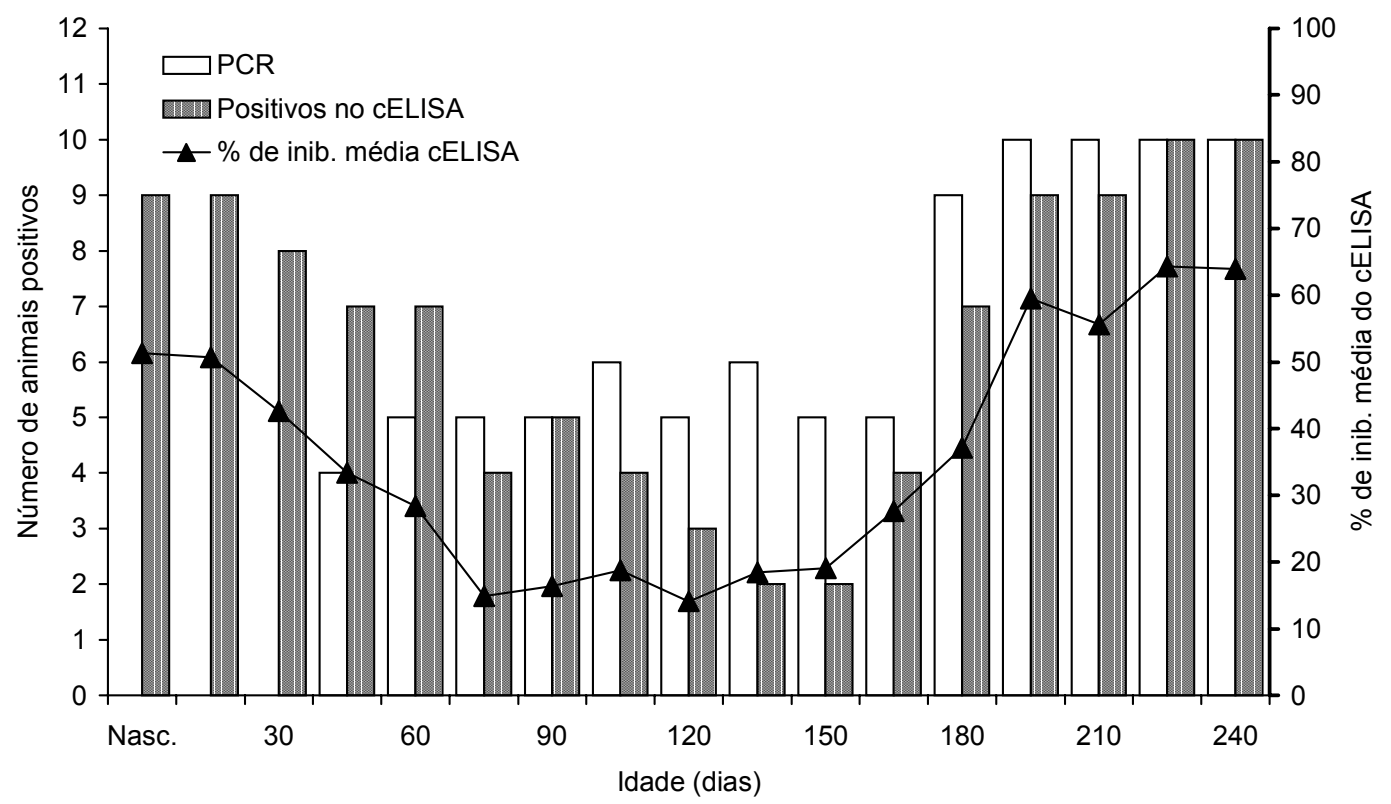

Figura 3. Distribuição dos animais positivos pela técnica de cELISA e da PCR, e a freqüência de distribuição da porcentagem de inibição média para o A. marginale pelo cELISA, realizada em onze bezerros, segundo a faixa etária, na propriedade B, na região de Londrina, PR, entre agosto de 2001 a novembro de 2002.

Andrade et al. (2001) realizaram estudo semelhante, monitorando dez bezerros da raça Holandesa, mensalmente, do nascimento (média de 2 a 20 dias de idade) até um ano de vida, pelo cELISA. Os autores observaram uma queda mais tardia dos níveis de anticorpos séricos, quando comparado aos animais da propriedade $\mathrm{A}$, mas semelhantes aos resultados obtidos na propriedade B. O maior número de animais negativos foi detectado próximo aos três meses de idade e os níveis de anticorpos começaram a aumentar a partir do $5^{\circ}$ mês de vida, permanecendo elevados até o final do experimento, quando os animais já tinham um ano de vida.

Yoshihara et al. (2003) monitorando 14 bezerros da raça Nelore a cada 30 dias, do nascimento até seis meses de idade, pelo teste de cELISA, 
observaram que os níveis de anticorpos séricos caíram rapidamente, sendo que aos 30 dias de idade apenas três animais eram positivos e a partir dos 60 dias os títulos voltaram a aumentar, elevando o número de animais positivos, atingindo o maior número com 180 dias de idade, quando 13 dos 14 animais eram sororreagentes para A. marginale.

Madruga et al. (1987) monitorando bezerros mestiços da raça Nelore, desde o nascimento até os 210 dias de idade, detectaram uma queda de anticorpos colostrais contra $A$. marginale com idade média de 47 dias, indicando o desaparecimento da imunidade humoral adquirida passivamente ou sua presença em níveis extremamente baixos. Em outro trabalho Madruga et al. (1985), examinando 50 bezerros da raça Nelore, Ibagé e mestiços, relataram que o número de animais sorologicamente negativos aumentou aos 30 dias e atingiu valores máximos aos 60 dias, sugerindo que em torno de 60 dias de idade há uma população de bezerros com risco potencial de contrair a infecção e apresentar sinais clínicos da doença. Nesse trabalho, esse período crítico foi diferente para as duas propriedades. Na propriedade A foi aos 45 dias de idade e na propriedade B, entre os 135 e 150 dias de vida, onde podemos observar o menor número de animais soropositivos em ambas as propriedades.

Da mesma forma que ocorreu nas vacas, parece que a maior quantidade de carrapatos observados nos animais na propriedade $\mathrm{A}$, não influenciou as médias dos níveis parasitêmicos que apresentaram valores semelhantes nas duas propriedades, oscilando entre zero e $1.1 \%$ no período do experimento, mas ficou evidente que a infecção natural dos bezerros foi dependente da queda dos níveis de anticorpos colostrais e exposição gradativa aos carrapatos observado nesses animais. Em função destes parâmetros os bezerros da propriedade A infectaramse com o A. marginale mais precocemente e os da propriedade B mais tardiamente (Figura 4).

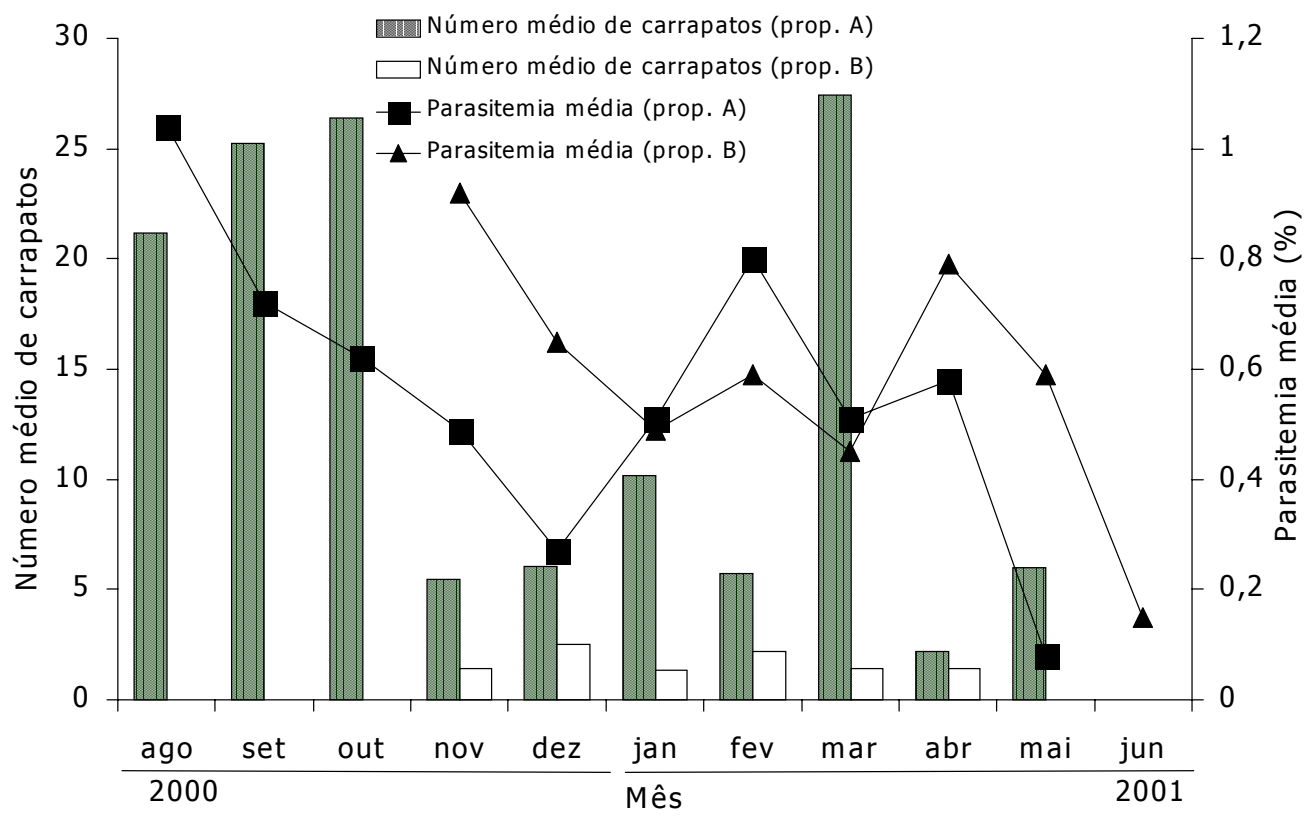

Figura 4. Distribuição da freqüência média do número de carrapatos e parasitemia em vacas da raça Holandesa durante o período de monitoramento dos animais nas propriedades A e B, na região de Londrina, PR 
Não se detectou alterações no hematócrito dos animais examinados, exceto um animal na propriedade $\mathrm{A}$, onde se constatou $40.2 \%$ de parasitemia e $13 \%$ de volume globular, caracterizando um quadro clínico de anaplasmose, mas nenhuma droga que tenha ação contra $A$. marginale foi utilizada e o animal recuperou-se espontaneamente.

Os valores do volume globular, avaliado pela técnica de microhematócrito, permaneceram entre 34 e $42 \%$, valores que estão dentro dos parâmetros de normalidade para a espécie (FELDMANN; ZINKC; JAIN, 2000).

A transmissão transplacentária, citada na literatura (WANDERA; MUNYUA, 1971; BIRD, 1973; PASSOS; LIMA, 1984; RIBEIRO et al., 1995) não foi constatada neste trabalho, embora tenha sido examinado sangue dos animais no dia do nascimento, pela PCR e laminas com esfregaços de sangue corado pelo Giemsa, não se detectou a infecção intra-uterina, neste caso, não significa que ela não ocorra na região. Sua ausência pode ser explicada pelo reduzido número de bezerros examinados, uma vez que a freqüência natural deste evento é baixa.

A luz dos conhecimentos atuais sobre a anaplasmose, doença amplamente disseminada nas regiões tropicais e subtropicais criadoras de bovinos, pode-se concluir que o equilíbrio entre o parasita e o hospedeiro depende também de um equilíbrio perfeito na natureza, de seus mais importantes vetores, representado por diferentes espécies de carrapatos. Embora a epidemiologia e as condições ambientais que favorecem ou desfavorecem o ressurgimento da doença, sejam bem conhecidos, estudos regionais mostram que pequenas alterações de manejo envolvendo os bezerros e os animais adultos podem provocar diferenças significativas na dinâmica da infecção, como ficou evidenciado neste trabalho.

\section{Conclusões}

Considerando-se os resultados obtidos nas condições que foi realizado esse trabalho pode concluir que:

1. A infecção natural dos bezerros pelo $A$. marginale após o nascimento foi mais dependente dos níveis de anticorpos colostrais absorvidos do que da intensidade da infestação pelo $B$. microplus.

2. A infecção dos bezerros pelo A. marginale foi subseqüente às primeiras infestações pelo $B$. microplus, mas os níveis de infestação pelo carrapato não influenciaram as médias de parasitemia, que se mantiveram baixas tanto nos bezerros como nas vacas em ambas as propriedades.

3. As diferenças de manejo existentes nas duas propriedades tiveram influência nos níveis de anticorpos das vacas e bezerros e no período de infecção natural dos bezerros.

\section{Referências}

ALFIERE, A. F. Caracterização dos genótipos G(VP7) e P(VP4) de Rotavírus grupo A de origem animal (bovina e suína) e humana pela Reação em Cadeia pela Polimerase (Multiplex RT-PCR). 1999. Tese (Doutorado) - Faculdade de Medicina Veterinária e Zootecnia, Universidade de São Paulo, São Paulo, 1999.

ALONSO, M.; ARRELANO-COSTA, C.; CERESER, V.H.; CORDOVES, C. O.; GUGLIELMONE, A. A.; KESSLER, R. H.; MANGOLD, A. J.; NARI, A.; PATARROYO, J. H.; SOLARI, M. A.; VEGA, C. A.; VIZCAINO, O.; CAMUS, E. Epidemiology of bovine anaplasmosis and babesiosis in Latin America and the Caribbean. Revue Scientifique et Technique Office Inernational des Épizooties, Paris, v.11, n.3, p.713-733, 1992.

ANDRADE, G. M.; VIDOTTO, O.; VIDOTTO, M. C.; YOSHIHARA, E.; KANO, F. S.; AMARAL, C. H. Soroprevalência de Anaplasma marginale em bovinos leiteiros e estudos sobre a dinâmica da infecção natural em bezerros holandeses no Sul do Brasil. Semina, Londrina, v.22, n.2, p.155-159, 2001. 
BIRD, J. E. Neonatal anaplasmosis in a calf. Journal/South African Veterinary Association, Pretoria, v.44, n.1, p.6970,1973

BOOM, R.; SOL, C. J.; SALIMANS, M. M.; JANSEN, C. L.; WERTHEIM-VAN DILLEN, P. M., VAN DER NOORDAA, J. Apid and simple method for purification of nucleic acids. Journal of Clinical Microbiology, Washington, v.28, n.3, p.495-503, 1990.

CONNELL, M. L.; HALL, W. T. K. Transmission of Anaplasma marginale by the cattle tick. Boophilus Microplus, Brisbane, v.31, n.3, p.185-195, 1972.

DUMLER, J. S.; BARBET, A. F.; BEKKER, C. P.; DASCH, G. A.; PALMER, G. H.; RAY, S. C.; RIKIHISA, Y.; RURANGIRWA, F. R. Reorganization of genera in families Rickettsiaceae and Anasplamataceae in the order Rickettsiales: unification of some species of Ehrlichia with Anaplasma, Cowdria with Ehrlichia with Neorickettsia, descriptions of six new species combinations and designation of Ehrlichia equi and "EGH agent" as subjective synonyms of Ehrlichia phagocytophila. International Journal of Systematic and Evolutionary Microbiology, Spencers Wood, v.51, p.21452165, 2001.

ERIKS, I. S.; PALMER, G. H.; MCGUIRE, T. C.; ALLRED, D. R.; BARBET, A. F. Detection and qualitation of Anaplasma marginale in carrier cattle by using a nucleic acid probe. Journal of Clinical Microbiology, Washington, v.27, n.2, p.279-284, 1989.

FARIAS, N. A. Diagnóstico e controle da Tristeza Parasitária bovina. Guaíba: Agropecuária, 1995.

FELDMANN, B. F.; ZINKC, J. G.; JAIN, N. C. Schalm's veterinary hematology. 5.ed. Philadelphia: Lippincott Williams \& Wilkins, 2000.

IAPAR. (Instituto Agronômico do Paraná). Cartas climáticas do Estado do Paraná. Londrina, 2002.

INSTITUTO INTERAMERICANO DE COOPERATION PARA LA AGRICULTURA. Tecnicas para el diagnostico de babesisosis y anaplasmosis. Costa Rica, 1984. (Serie Salud Animal, 8).

KESSLER, R. H. Considerações sobre a transmissão de Anaplasma marginale. Pesquisa Veterinária Brasileira, Seropedica, v.21, n.4, p.177-179, 2001.

KIESER, S. T.; ERIKS, I. S.; PALMER, G. H. Cyclic rickettsemia during persistent Anaplasma marginale infection of cattle. Infection and Immunity., Washington, v. 58, n.4, p.1117-1119, 1990.

KNOWLES, D. P.; TORIONI DE ECHAIDE, S.; PALMER, G. H.; MCGUIRE, T. C.; STILLER, D.; MCELWAIN, T. Antibody against an Anaplasma marginale MSP5 epitope common to tick and erythrocyte stages identifies persistently infected cattle. Journal of Clinical Microbiology, Washington, v.34, n.9, p.2225-2230, 1996.

MADRUGA, C. R.; KESSLER, R. H.; GOMES, R. H.; SCHENK, M. A. M.; ANDRADE, D. F. Níveis de anticorpos e parasitemia de Anaplasma marginale em área enzoótica, nos bezerros da raça Nelore, Ibagé e cruzamentos de Nelore. Pesquisa Agropecuária Brasileira, Brasília, v.20, n.1,p.135-142, 1985.

MADRUGA, C. R.; HORNER, M. R.; SCHENK, M. A. M.; CURVO, J. B. E. Avaliação preliminar de parâmetros epidemiológicos da Tristeza Parasitária Bovina no Mato Grosso do Sul. Campo Grande: Embrapa/CNPGC, 1987. (Boletim de pesquisa, n.38).

MARTINS, J. R.; CORRÊA, B. L. Babesiose e anaplasmose bovina: aspectos destas enfermidades. Pesquisa Agropecuária Gaúcha, Porto Alegre, v.1, p.51-58, 1995.

MASON, C. A.; NORVAL, R. A. I. The transfer of Boophilus microplus (Acarina: Ixodidae) from infested to uninfested cattle under field conditions. Veterinary Parasitology, Amsterdam, v.8, p.185-188, 1981.

PALMER, G. H.; RURANGIRWA, K. M.; BROWN, W. C. Tick- born diseases: molecular basis for vaccine development against the ehrlichial pathogen Anaplasma marginale. Parasitology Today, Limerick, v.17, n.7, 1999.

PALMER, G. H.; BROWN, W. C.; RURANGIRWA, F. R. Antigenic variation in the persistence and transmission of the Ehrlichia Anaplasma marginale. Microbes and Infectious, Paris, v.2, p.167-176, 2000.

PASSOS, L. M. F.; LIMA, J. D. Diagnóstico de anaplasmose bovina congênita em Minas Gerais. Arquivo Brasileiro de Medicina Veterinária e Zootecnia, Belo Horizonte, v.36, n.6, p.743-744, 1984.

RIBEIRO, M. F. B.; LIMA, J. D. Morphology and development of Anaplasma marginale in midgut of engorged female ticks of Boophilus microplus. Veterinary Parasitolology, Amsterdam, v.61, n.1-2, p.31-39, 1996.

RIBEIRO, M. F. B.; LIMA, J. D.; GUIMARÃES, A. M.; MARTINS, N. E. Transmissão congênita da anaplasmose bovina. Arquivo Brasileiro de Medicina Veterinária e Zootecnia, Belo Horizonte, v.47, n.3, p.297-304, 1995.

RISTIC, M. Anaplasmosis. In: RISTIC, M.; McINTYRE, I. (Ed.). Diseases of cattle in the tropics : economic and zoonotic relevance. The Hague: Martinus Nijhoff Publishers, 1981.p.327-344.

SASAKI, M.; DAVIS, C. L.; LARSON, B. L. Production and turnover for IgG1 and IgG2 immunoglobulins in the bovine around parturition. Journal of Dairy Science, Savoy, v.59, n.12, p.2046-2055, 1976. 
SHIMADA, M. K. Estudo da dinâmica da infecção de Anaplasma marginale (THEILER, 1910) em larvas do carrapato Boophilus microplus (CANESTRINI, 1887). 2002. Dissertação (Mestrado em Ciência Animal) Universidade Estadual de Londrina, Londrina, 2002.

STILLER, D.; COAN, M. E. Recent developments in elucidation tick vetor relationship for anaplasmosis and equine piroplasmosis. Veterinary Prasitology, Amsterdam, v.57, n.1-3, p.97-108, 1995.

THEIL, K. W.; McCLOSELY, C. M.; SAIF, L. J.; REDMAN, D. R.; BOHI, E. H.; HANCOCK, D. D.; KOHLER, E. M.; MORHEAD, P. D. Rapid and simple method of preparing rotaviral double-strand ribonucleic acid for analysis by polyacrilamide gel electrophoresis. Journal Clinical Microbiology, Washington, v.14, p.273-280, 1981.

VANZINI, V. R.; RAMIREZ, L. M. Babesiosis y anaplasmosis bovina: diagnostico, epidemiologia y control. Revista de Investigação Agropecuária, Buenos Aires, v.25, n.3, p.137-190, 1994.
VIEIRA, S. M. Introdução a bioestatística. 3.ed. Rio de Janeiro: Campus, 1998.

WANDERA, J. G.; MUNYUA, W. K. Severe anaplasmosis in a 4-day-old calf. Bulletin of Epizootic Diseases of Africa, Nairobi, v.19, p.219-221, 1971.

WHARTON, R. H.; UTECH, K. B. W. The relation between engorgement and dropping of Boophilus microplus (Canestrini, 1889) (Ixodidae) to the assessment of tick numbers on cattle. Journal of the Australian Entomological Society, Sydney, v.9, p.171-182, 1970.

YOSHIHARA, E.; VIDOTTO. O.; YAMAMURA, M. H.; MARANA, E. R. M.; PACHECO, R. C.; SILVEIRA, A. P. Studies of natural infection with Anaplasma marginale in Nelore cattle in the Umuarama municipality, Paraná State, Brazil. Revista Brasileira de Parasitologia Veterinária, Rio de Janeiro, n.1, v.12, p.21-26, 2003. 